\title{
Impact of Biotic Stress on Edaphic Features under two Important Medicinal Plants (Podophyllum hexandrum and Rumex acetosa L.) of Kashmir Valley, J \& K, India
}

\author{
Aijaz Ahmad Sheikh ${ }^{1}$, S.A. Shameem ${ }^{2} *$ and Naseer Ahmad ${ }^{3}$
}

${ }^{1}$ P.G. Department of Environmental Sciences, S.P.College Srinagar, 190001/ Presently, Department of Environmental Sciences, Govt. Degree College Tangmarg, Brarmulla, 193402

${ }^{2}$ P.G. Department of Environmental Sciences, S.P.College Srinagar, 190001/ Presently

Division of Environmental Sciences, SKUAST-K, Shalimar Campus, 190025

${ }^{3}$ Department of Environmental Sciences, S.P.College Srinagar, 190001

*Corresponding author

\begin{tabular}{|l|}
\hline Key w o r d s \\
Soil, Medicinal, \\
$\begin{array}{l}\text { Podophyllum, } \\
\text { Rumex, Seasons }\end{array}$ \\
\hline Article Info \\
\hline $\begin{array}{l}\text { Accepted: } \\
18 \text { May } 2020 \\
\text { Available Online: } \\
\text { 10 June } 2020\end{array}$ \\
\hline
\end{tabular}

\section{A B S T R A C T}

The present study was conducted to assess the status of edaphic features under two medicinal plants viz., Podophyllum hexandrum and Rumex acetosa at three high altitude sites (site I, Boisaran Pahalgam; site II, Betab valley Pahalgam; and site III, the Lolab valley, Kupwara) in Kashmir valley, J \&K. Results of soil characteristics revealed soil moisture content slightly high under Podophyllum hexandrum (45.30\%, site II, summer to $14.97 \%$, site I, summer) season and low under Rumex acetosa (16.5\%, site I, winter to $36.7 \%$, site II, summer). $\mathrm{pH}$ of soil samples depicted slightly alkaline (7.21, summer, site I) of Podophyllum hexandrum to acidic (5.27, autumn, site I) under Rumex acetosa. The seasonal trend showed $\mathrm{pH}$ high in summer season and low in autumn in Rumex acetosa while as it was high in summer and decline in winter season. Organic carbon of two plants soils recorded high carbon content under Rumex acetosa soil $(6.61 \%$, autumn, site I) and low under Podophyllum hexandrum (2.12\%, summer, site II). Nitrogen content of soil recorded maximum percentage of Rumex acetosa $(0.35 \%$, autumn, site I) and minimum under Podophyllum hexandrum ( $0.10 \%$ site II, summer season). Assessment of loss on ignition was recoded high $8.02 \%$, site I, autumn and, low $4.04 \%$ site III in the same season in Rumex acetosa soil samples. Among three sites, site I overall showed dominance in soil nutrients was recorded in the summer/autumn season depicted high value. The overall results obtained in the present study revealed that Rumex acetosa soil dominated in nutrients status and Podophyllum hexandrum soil was recorded under stress due to various factors include slope aspect, micro-climate, seasonal influences and biotic stress which changed the soil composition in two medicinal plants. The study thus recommends immediate scientific measures to protect and mitigate further deterioration of soil status from degradation under two medicinal. 


\section{Introduction}

It is well known that natural ecosystems are continuously being disturbed throughout the world. Several thousands of medicinal plants are being destroyed due to various causes like human neglect, industrialization, uncontrolled deforestation, and indiscriminate collection. There are also many other potential causes responsible for the rarity in medicinal plant species, such as habitat specificity, habitat alteration, narrow range of distribution, land use disturbance, the introduction of nonnatives, climate change, heavy livestock grazing, an explosion of the human population, fragmentation and degradation of population and genetic drift (Kala, 2005 and Weekley, 2001). High altitude medicinal plants are of great concern throughout the Himalayan region, because they are important for traditional health care and in large scale collection for trade. Moreover, it is estimated that, about 3000 plants were recognized in India for their medicinal value, and of them, 200 species are in wide use for their curative properties. World wide $80 \%$ of all synthetic drugs are derived from medicinal plants (Bauer and Brönstrup, 2014). According to the World Health Organization, the global market for plant-based medicines will hit 5 trillion US dollar by 2030 (Anon., 2013).

Plant nutrition is the major factor which influences the growth and development of a plant. Inadequate supply of plant nutrients is detrimental to plant growth having a negative effect on the yield. Thus, the maximum yield can be obtained with optimum nutrient levels. Nutrient deficiencies in plants are often made most evident by plant physiological responses. Nutrient deficiency symptoms tend to occur in three major patterns: localized to the younger tissues, localized to the more mature tissues, or widely distributed across the plant (Boroomand and Grouh, 2011). Stress in plants refers to external conditions that adversely affect growth, development, or productivity of plants (Verma, et al., 2013). Stresses trigger a wide range of plant responses like altered gene expression, cellular metabolism, changes in growth rates, crop yields, etc. Plant stress usually reflects some sudden changes in environmental conditions. However in stress-tolerant plant species, exposure to particular stress leads to acclimation to that specific stress in a time time-dependent manner (Verma et al., 2013). Plant stress can be divided into two primary categories namely abiotic stress and biotic stress. Abiotic stress imposed on plants by the environment may be either physical or chemical, while biotic stress exposed to the crop plants is a biological unit like diseases, insects, etc. Some stresses to the plants injured them as such that plants exhibit several metabolic dysfunctions The plants can be recovered from injuries if the stress is mild or of short term as the effect is temporary while as severe stresses leads to death of crop plants by preventing flowering, seed formation and induce senescence (Verma et al., 2013).

Soil is an important natural resource, as a key component of the mountain ecosystem, and it underpins our very existence through providing a wide range of food, feed, fiber and timber production, as well as through earth system functions that support the delivery of other "ecosystem services" (Dominati et al., 2010; Robinson, et al., 2017). The suitability of the soil for those productions is based on the quality of the soil's physical, chemical, and biological properties (Mobley, 2009; Khan, 2013). However, the spatial variability of soil properties in an ecosystem is significantly influenced by some environmental factors such as parent materials, topography, climate, vegetation, and disturbance due to human activities (Umali, 2012). Among these factors, it is well recognized that topographic 
gradients (e.g., slope position, slope aspect, slope gradient) may play the most essential role due to their influence on the shape of the land surface, thereby dictating the distribution of local and regional microclimates by changing the pattern of precipitation, temperature and relative humidity (Tsui, 2004; Yimer, 2006). Topography-induced microclimate differences, in turn, can cause a significant change in plant growth and soil properties, which will drastically affect the structures and functions of ecosystems (Hook and Burke, 2000; Lozano-García et al., 2016; Sun et al., 2014; Zhang, 2018 and Begum et al., 2010). As a major topographical parameter, the slope position, i.e., the relative height position along the hill's side slope could also significantly change the soil physico-chemical properties by controlling the movement of water and material in a hill slope and contributing to the spatial deference of soil properties (Begum et al., 2010; Khormali et al., 2007). The objective of this study was to investigate the impact of biotic interference on soil characteristics of two important medicinal plants of Pahalgam valley, south Kashmir, Anantnag district of Jammu \& Kashmir Union Territory.

\section{Materials and Methods}

Composite soil samples were collected using a soil augur at three selected sites. Soil samples were collected on a monthly basis. The collected samples were homogenized by hand mixing and sieved through a $2 \mathrm{~mm}$ mesh to remove large fresh plant material (roots and shoots) and pebbles. Finally, the samples were air-dried for further analysis (Jackson, 1967). Briefly, soil (pH) $\mathrm{pH}$ was measured with digital $\mathrm{pH}$ meter (model Delux-101E) using a soil: water ratio of $1: 2.5$. Soil organic matter $(\%)$ was tested by using the dichromate oxidation method (Walkey and Black's rapid titration method: Walkey and Black, 1934). Moisture content (\%) was analyzed by
(Michael, 1984). Soil total nitrogen (\%) was determined by using the automatic Kjeldahl method (Piper, 1966).

\section{Study area and sites}

Pahalgam is located between $34^{\circ} 01^{\prime} \mathrm{N}$ latitude and $75^{\circ} 11$ ' $\mathrm{E}$ longitudes at an elevation of 2,740 meters in Anantnag district of Union territory of Jammu and Kashmir, nearly 96 kilometers away from the summer capital, Srinagar. The valley is located between coordinates of $34^{\circ} 01^{\prime} \mathrm{N}$ latitude and $75^{\circ} 11^{\prime}$ E longitudes at an elevation of 2,740 meters. The present study was conducted on a seasonal basis at three different study sites Kashmir valley. The site-wise description of the threes selected sites is given under:

Site I: Baisaran Pahalgam: The site is located at an altitudinal range of $2,900 \mathrm{~m}$ masl in the Pahalgam valley.

Site II: Betab valley: The site is located about 6-7 kilometers away from Pahalgam town at an altitudinal range of $2,450 \mathrm{~m}$ masl.

Site III: The Lolab valley: Lolab is situated in the north of Kashmir valley, district Kupwara. It is situated between geographical coordinates of $34^{0} 25^{\prime}$ and $34^{\circ} 42^{\prime} \mathrm{N}$ latitudes and $74^{\circ} 15^{\prime}$ and $74^{0} 32^{\prime}$ E longitudes, at a distance of $90 \mathrm{~km}$ northwest of the Srinagar.

\section{Description of selected plants}

\section{Rumex acetosa $L$.}

Rumex acetosa L. (common sorrel) locally called as "Abej" in Kashmir is an herbaceous perennial plant belonging to order Carophyllales and buckwheat family Polygonaceae. This plant is native to the British Isles and can also be found in Britain, most of Europe, North America, Greenland, and temperate Asia. The leaves of the Rumex 
acetosa are acidic in taste and contain high levels of oxalic acid. Rumex acetosa is reported to have medicinal properties: an astringent, for curing stomach problems, chest problems, cancer \& tumors, and also acts as a diuretic. In Kashmir Himalaya, the young leaves are also used as vegetables.

\section{Podophyllum hexandrum}

Podophyllum hexandrum is a source of various biologically important metabolites and possess antioxidant, anti-inflammatory, antifungal, cytotoxic and radioprotection activity. It is an important medicinal plant known for valuable drug podophylotoxin which is effective against various diseases including warts and tumors growth of skin and possesses different properties such as purgative, laxative, cholagogue and emetic. In India Podophyllum hexandrum is mostly found in Alpine Himalayas (3000-4000 msl) of Jammu and Kashmir, Himachal Pradesh, Sikkim, Uttaranchal and Arunachal Pradesh. In Kashmir it has been used in traditional system of medicine from time immemorial and is locally known as Banwangun, since its red colour fruit (berry) is of the size of small brinjal. Podophyllum hexandrum grows from 12 to 18 inches high with deeply lobed leaves, fleshy stems, which rise straight up from the soil.

\section{Results and Discussion}

Soil, the source of infinite life is the most vital and precious natural resource, and not renewable in a short time. Soil fertility refers to the ability of soil to sustain agricultural plant growth, and result with consistent yields of high quality. Soil fertility is a dynamic natural property and it can change under the influence of natural and human induced factors. Parent material, climate, topographical conditions, and natural vegetation are the natural factors affecting the soil fertility to a great extent. Among the anthropogenic factors, nutrient management practice is one of the most important factors affecting soil fertility. Soil physico-chemical properties, as an important indicator of soil quality, possess not only obvious differences but also interactions and close associations with each other, which jointly determine the quality of the soil (García-Ruiz et al., 2009). The physico-chemical characteristics of soil under two important medicinal plants are depicted in Figure (1-12).

The Soil moisture content of two medicinal plants varied from $16.5 \%-36.7 \%$ (Rumex acetosa) and 14.97\%-45.30\% (Podophyllum hexandrum). Season and site-wise trend depicted soil moisture percent high at site II in summer season under Rumex acetosa and low at site $I$ in the same season under Podophyllum hexandrum. Comparing mean values of soil moisture content, Podophyllum hexandrum showed high/low value (18.82\%, site I and $38.07 \%$, site II) and ranged between (19.23\%-28.36\%) in Rumex acetosa. The Summer season was at par with the other two seasons in soil moisture content in two medicinal plants (Figure 1-2).

The role of $\mathrm{pH}$ is to control the solubility of nutrients in the soil. Soil $\mathrm{pH}$ of Rumex acetosa at three sites ranged between (5.27 site I-site II, 6.70) and under Podophyllum hexandrum (5.59, site II-7.21, site I). Summer season showed high soil $\mathrm{pH}$ in two selected plants with a decline in autumn till the winter season. The soil $\mathrm{pH}$ overall showed acidic to alkaline character. Mean values however show $\mathrm{pH}$ in acidic range in Rumxex acetosa (5.46-5.79) to nearly neutral in Podophyllum hexandrum (6.11-6.74) Figure 3-4. A similar trend in $\mathrm{pH}$ was recorded by Liu et al., 2020. Acidity directly affects plant growth. Acidity $(\mathrm{pH})$ has a significant effect on the distribution of plant species. The role of $\mathrm{pH}$ is to control the solubility of nutrients in the 
soil. Our results are in agreement with those reported by Janisova (2005), Virtanen et al., (2006) and Zolfaghari et al., (2010) and Akbarlou and Nodehi (2016).

Organic carbon among two medicinal plants recorded high in Rumex acetosa soil with variation between $(3.46 \%$, site II- $6.61 \%$, site I). At Podophyllum hexandrum, it depicts high value $(5.35 \%$, site III) and low at site II $(2.12 \%)$. Seasonal trend projected high carbon content in soil during autumn season followed by winter and then summer season. Mean values recorded high carbon content in Rumex acetosa (4.80\%-5.62\%) and low under Podophyllum hexandrum (3.44\%-4.59\%) Figure 5-6.

Loss on ignition of two plant soils showed both high/low values recorded by Rumex acetosa soil during the autumn season at site I and site II (8.02\% and $4.04 \%)$. However, at Podophyllum hexandrum, it varied between (5.61\%, site I, autumn-7.95\%, site III, summer). Seasonal change in loss on ignition of Rumex acetosa depicted maximum in summer/autumn season and decline in winter. Podophyllum hexandrum showed maximum value in summer/winter and a decline in the autumn season. Mean values showed a difference of (4.66\%-7.12\%, Rumex acetosa) and (5.74\%-7.66\%, Podophyllum hexandrum) Figure 7-8. Nitrogen in Rumex acetosa soil was recorded high $(0.17 \%$, site II- $0.35 \%$, site I) comparatively to Podophyllum hexandrum (0.10\%, siteII- $0.26 \%$, site III) with average value ranges between $0.23 \%-0.29 \%$ (Rumex acetosa) and $0.17 \%-0.22 \%$ (Podophyllum hexandrum). Summer season showed high nitrogen content at both plants followed by winter and summer season in two plants (Figure 9-10).

Kooch et al., (2007) in the study of ecological distribution of indicator species and effective soil factors in Mazandaran province showed that the distribution of vegetation was correlated with soil properties such as soil texture, organic matter, nitrogen, and $\mathrm{pH}$. Different types of soil have quite different physicochemical and biological properties, which have substantial effects on the growth, development, and active constituents of medicinal plants (Li and Xiao, 2012). Thus, different plants have different demands for the appropriate type(s) of soil. In the present study organic carbon and total nitrogen varied between (OC, 2.12\%-6.61\%) and (TN, 0.10\%-0.35\%). Liu et al., (2007), reported that the type and texture of soil were closely related to the growth and development of medicinal plants and that loam soil was the relatively ideal type of soil for the cultivation of root/stem-types of medicinal plants. Among which, soil serves as an essential medium for supporting plant growth and development, and thus, it has important influences on the growth, development and the medicinal quality of herb plants (Liu et al., 2007).

Plant nutrition is the major factor which influences the growth and development of plant. Inadequate supply of plant nutrients is detrimental to plant growth and harms the yield. Thus, the maximum yield can be obtained with optimum nutrient levels. Nitrogen in Rumex acetosa soil was recorded high $(0.35 \%$, site I) comparatively to Podophyllum hexandrum $(0.26 \%$, site III) with average value ranges between $0.23 \%$ $0.29 \%$ (Rumex acetosa) and 0.17\%-0.22\% (Podophyllum hexandrum). Since they are sessile organisms, plants have evolved numerous mechanisms for accommodating changes arising in their fluctuating growth conditions to enable functional flexibility under the influence of environmental factors without affecting cellular and developmental physiological processes (Yang et al., 2018; Arnold et al., 2019) by producing a repertoire of secondary metabolites (SMs) that play a 
variety of roles in response to changing environment, growth, and development (Kroymann, 2011; Berini et al., 2018). Taghipoor et al., (2008) investigated the effects of environmental factors on the distribution of species. Their results showed that the most important factors affecting the distribution and establishment of dominant species were moisture, acidity, and altitude from sea level.

One of the most important physico-chemical properties of soil, soil $\mathrm{pH}$ directly affects plant growth and microbial activities, and most plants are suitable for growth in an environment where $\mathrm{pH}$ is neutral (Simek, and Cooper, 2002). Conversely, excessive $\mathrm{pH}$ will inhibit plant root growth, thereby reducing the accumulation of soil organic matter. Hence, a suitable $\mathrm{pH}$ is beneficial to the decomposition of soil organic matter by micro-organisms and affects the release of phosphorus ( $\mathrm{Yu}$ et al., 2017). Soil pH influences the availability of plant nutrients and it is a good indicator of forest fertility (Black, 1968). In the present study soil $\mathrm{pH}$ did not show much difference site wise and season wise (Figure 1-2). Soil $\mathrm{pH}$ of Rumex acetosa was acidic to nearly neutral with variation between (5.27-6.70) and acidic to nearly alkaline under Podophyllum hexandrum (5.59-7.21). The acidic to nearly neutral $\mathrm{pH}$ values has also been reported in forest sites by Kala, 2005; Shameem et al., 2011. Mean values of soil $\mathrm{pH}$ reflect acidic soil nature with significant difference (5.66, site I; 6.46, site II) under Rumex acetosa and (6.11, site II to 6.74, site I) under Podophyllum hexandrum (Figure 1$2)$. In concurrent to the present study acidic soil $\mathrm{pH}$ (5 to 6) was already reported by Kharkwal and Rawat (2010). However, low $\mathrm{pH}$ at site I (5.27) Rumex acetosa and (5.59) under Podophyllum hexandrum at site II were due to higher organic matter and continuous decomposition of surface litter over the years. Similar results about these observations were also reported by Raina (1988). Comparatively, the lowest $\mathrm{pH}$ value was observed during the dry season (autumn) compared to two seasons. Concurrent results were obtained by Buckman and Brady (1967) and Keoghh and Maple (1972). In general soils under both medicinal plants showed acidic approach. Nitrogen content of plantsoil recorded high/low content under Rumex acetosa at site I \& site $\operatorname{III}(0.35 \%$, site I, autumn and $0.17 \%$, site II, summer) with the average value of $(0.23 \%-0.29 \%)$. In Podophyllum hexandrum soil nitrogen ranged between $(0.10 \%-0.26 \%)$ with high in autumn at site III and low in summer season at site II with average mean values $(0.17 \%-0.22 \%)$ Figure 9-10.

The High content of nitrogen at site I and site III was due to less biotic and abiotic pressure which affects the normal growth and development as well as internal and external qualities of plants ( $\mathrm{Li}$ and Xiao, 2012). Increase stress to soil nitrogen indicates a lack of nitrogen-nutrient which leads to the accumulation of nitrogen-free secondary metabolites. Previous studies conducted on soil-plant interaction revealed nitrogen as the most important nutrient element required by plants reported by (Chen et al., 2016), thus supports the results obtained in this study. Significantly, the comprehensive assessment revealed that stress, sites, and season have significantly affected the soil nitrogen content of Podophyllum hexandrum (0.10\%-0.26\%) in the shape of biotic interference such as grazing, human disturbance, and tourist visitors. Important factors affecting the soil properties of two medicinal plants were climate, altitude, slope aspect, and changing season. Pertinent results comparing this study were also reported by Shameem et al., (2017). Furthermore, Nitrogen is reported to have a synergistic effect on the regulation of plant growth (Mengel and Kirkby, 1987; Marschner, 1995: Desai et al., 2014). The 
enhancement of growth characters might be ascribed to the influence of nitrogen, which is the chief constituent of protein and an important component of amino acids and co. enzymes, which are of considerable biological importance. Balky (1998), physiologically, nitrogen is mostly available to plants in the forms of ammonium; nitrate and preference for one of the two forms to be taken up by plants tend to be influenced by the plant species and soil conditions, including $\mathrm{pH}$ and soil temperatures. A High content of nitrogen was reported under Rumex acetosa $(0.17 \%$ $0.35 \%$ ) and low under Podophyllum hexandrum (0.10\%-0.26\%). Fertilization program in medicinal plants has two important objectives: high vegetative growth, high quantity and quality of secondary metabolites produced. Meeting these objectives could lead to high medicinal materials and increased medicinal value of a plant. Nitrogen content was recorded high at site I (0.35\%, Rumex acetosa) and site III
(0.26\%, Podophyllum hexandrum). Generally, nitrogen supply favor increased vegetative growth Argyropoulou et al., 2015.

Organic matter is one of the important components of soil whose amount and type are affected by climate and vegetation. Organic matter creates a good soil structure, increases capacity, and makes some changes in the acidity of soil and biological activity (Jafari et al., 2008). Sheikhhosseini and Noorbakhsh (2007) believe that the organic matter of soil plays a major role in supplying soil carbon and energy of heterotrophic micro-organisms. Soil organic matter is a complex mixture, which influences a series of soil properties and nutrient cycling, while soil enzymes are mainly adsorbed on the soil organic matter particles or combined with humus (Loveland, and Webb, 2003). Soil organic matter is one of the most important soil components, along with stabilizing soil structure and improving the infiltration rate.
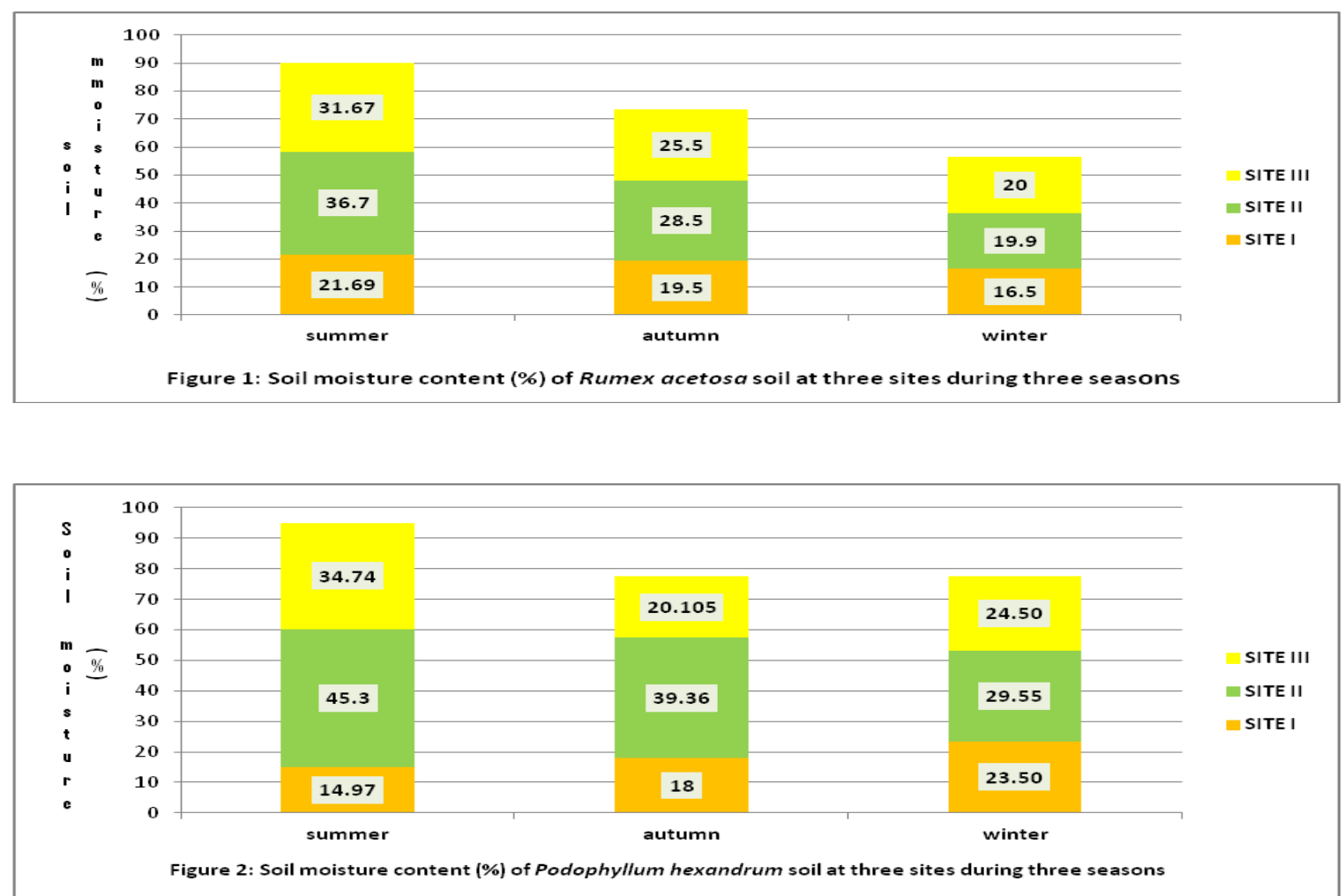

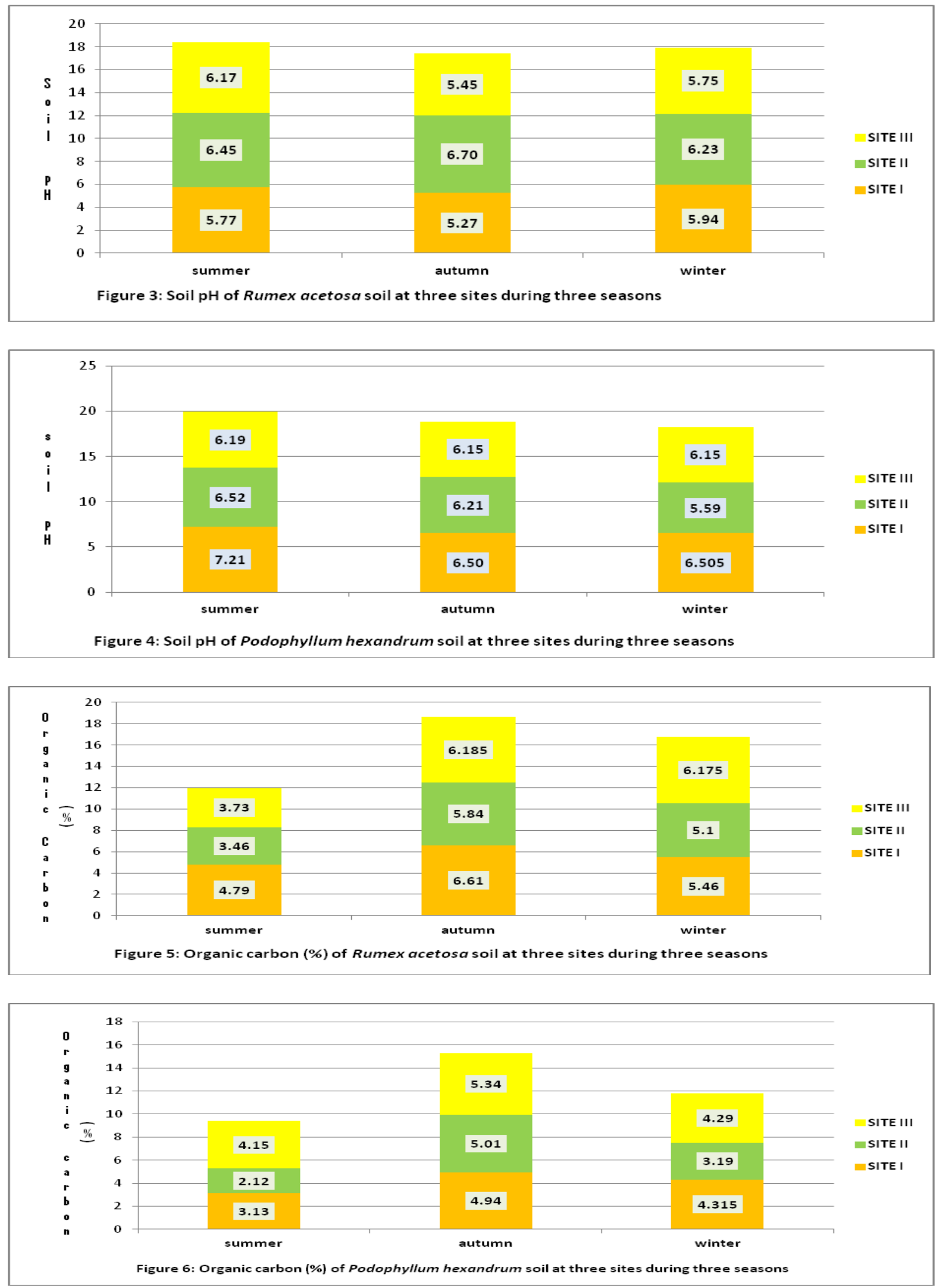

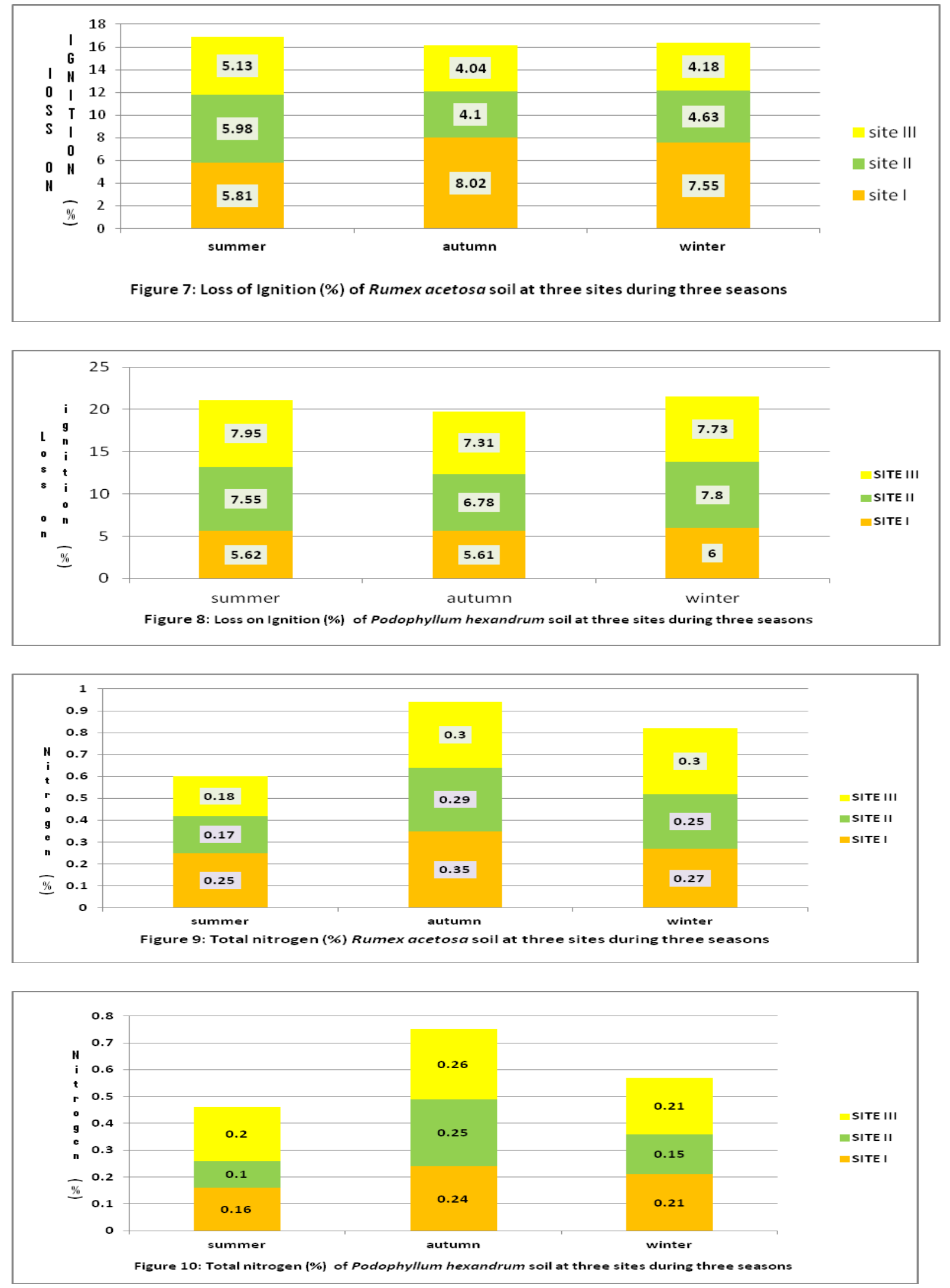

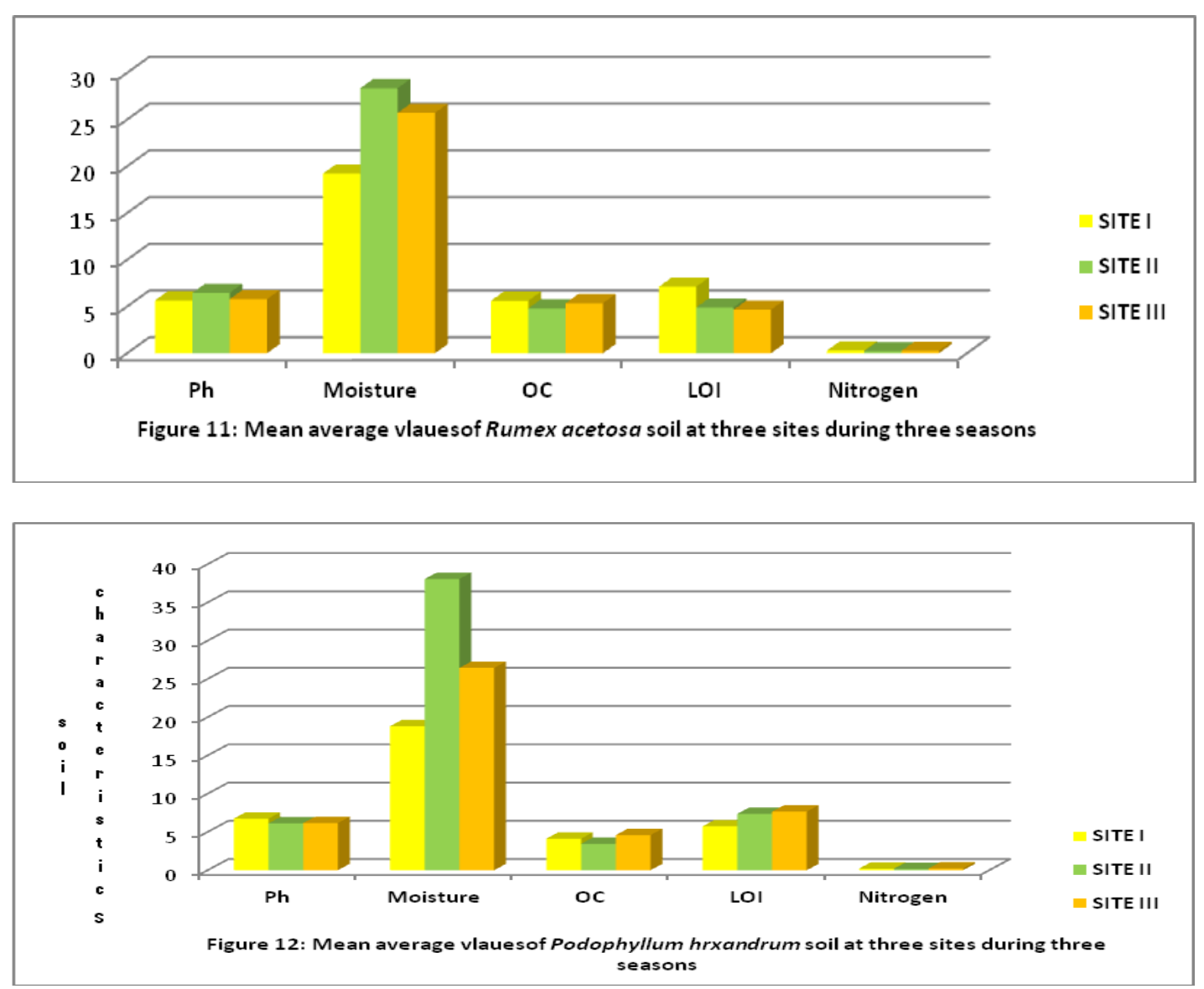

Organic carbon ranged from $(3.73 \%$, site III, summer) to $(6.61 \%$, site I, autumn) under Rumex acestosa and (2.12\%, summer, site II) to $(5.34 \%$ autumn, site III). Mean values depicted high range under Rumex acetosa soil (4.80\%-5.62\%) and low (3.44\% to $4.59 \%)$ under Podophyllum hexandrum Figure 5-6. In the comparison of two plants and three sites, organic carbon was found significantly high in Rumex acetosa soil at site I (4.79\%-6.61\%) Figure (5 and 6). Most of the N, P, and S remain bound to the soil organic matter, which is not degraded sufficiently under low temperature. Previously, nitrogen mineralization rate, soil organic matter degradation rate, and soil $\mathrm{P}$ content were found to decrease with temperature (Gao et al., 2014; Walz et al., 2017). Overall low percentage of organic carbon was observed at site II (Rumex acetosa 3.46; Podophyllum hexandrum 2.12,) under two plants soils. Therefore, low nutrient status of high altitude soil is the result of low temperature-induced decrease in mineralization and decomposition. Generally soil with SOM contents $<0.5 \%$ is considered poor and $>2.0 \%$ is desirable for agriculture (Hardy et al., 2013). Soil organic matter (soil organic matter) is an important factor determining the microbial community structure in the soil. The high organic carbon content in Rumex acestosa soil is due to a high amount of litter addition to these soils at three selected sites. Similar observations in accordance with the present study were also reported by (Kharkwal and Rawat, 2010; Kharkwal et al., 2009; Kumar et al., 2002; Shameem et al., 2017). The closed canopy in natural forests also minimizes erosion resulting in the accumulation of organic matter in the natural forest compared to 
pastures. Besides, the difference in vegetation type, species composition, and natural protection can be attributed to a high amount of organic carbon of Rumex acestosa soil (3.46\%-6.61\%). The reason meant for a lower percentage of organic carbon under Podophyllum hexandrum could be due to biotic stress mainly grazing and human disturbance which reduces soil organic matter/compacts the soil surface layer and ultimately increases surface runoff (Faizul et al., 1995). Moreover, topography has an indirect effect on plant community distribution and soil properties. Total nitrogen content of Rumex acestosa soil revealed higher values $(0.17 \%$, summer to $0.35 \%$, winter) compared to Podophyllum hexandrum $(0.10 \%$, summer to $0.26 \%$, autumn). The changes may be induced by environmental components that include local geo-climatic and seasonal changes, external conditions of temperature, light, humidity and developmental processes, among others and impact biomass production and biosynthesis of plant secondary metabolites (PSMs) (Berini et al., 2018; Morison and Lawlor, 1999; Ramakrishna and Ravishankar, 2011; Chetri et al., 2013; Zykin et al., 2018). Increased soil temperature is reported as a primary environmental factor that decreases the nitrogen mineralization processes thus influencing the bioavailability of soil nitrogen (Bu et al., 2015). Soil nitrogen was the most important factor limiting plant growth. One of the factors affecting the value of nitrogen is soil texture. According to Salardini (1979), clay soils have more $\mathrm{N}$ as compared with sandy soils due to the increased nitrogen retention by clay. Fahimipoor et al., (2010) reached similar results in their study. Though, the soil OC, LOI, and $\mathrm{N}$ content were found high in Rumex acetosa soil, their bioavailability to the living system is a major factor. Nitrogen associated with soil organic matter is not readily mineralized, thus comparatively high total $\mathrm{N}$ content of the soil at high altitude could be the result of high soil organic matter. Total nitrogen in agriculture soil is generally reported to vary from $0.10 \%$ to $0.15 \%$, thus the soil under two selected plants was comparatively rich in total nitrogen. However, during the summer season total nitrogen content was recorded lowest at two plant soils depicted a higher trend in autumn and winter Figure (9 and 10). The possible reason for higher organic matter and nitrogen content under Rumex acestosa soil may well be due to high moisture content and low decomposition rate (Bortharkur, 1992). The higher amount of humus and total nitrogen percent in such a landscape could be explained by a higher amount of available organic material present site I (Shourkaie et al., 2007). Similar seasonal variations in concurrence to the present study were also reported by several workers like Jenny (1930) and Jackman (1964). Sebastia (2004) showed that soil fertility is the main environmental factor in vegetation establishment particularly medicinal plants.

In conclusion, this study comprehended that the soil characteristics viz., soil $\mathrm{pH}$, organic carbon, nitrogen, moisture content, and loss on ignition overall showed high content at the site I and site II. Seasonal changes in soil nutrient properties depicted soil status good in summer/autumn season followed by winter season at two selected plants. Moreover, Rumex acetosa soil dominated in nutrients status and Podophyllum hexandrum reported slight in stress due to various factors including slope aspect, micro-climate, seasonal influences, and biotic stress. Furthermore, the impact on soil properties at selected study sites are increasing due to fuel fodder collection, illegal harvesting of medicinal herbs, deforestation, and frequent tourist visitors particularly in the summer season, therefore immediate protective measures required to maintain the soil health status of two selected medicinal plants. The 
study concluded that improvement in soil characteristics of two selected medicinal plants at three sites can be achieved through sustainable and regular monitoring of biotic interference of livestock grazing and human disturbance at different seasonal.

\section{Acknowledgments}

The authors are extremely grateful to all those who contribute efficiently to the accomplishment of the research work. Special thanks are affirmed for Prof. (Dr.) Abdul Hai, Head, Department of Environmental Sciences, S.P. College/presently Head, Department of Zoology, Govt. Degree College Bemina, Srinagar for his incessant support, facilities, and supervision.

\section{References}

Akbarlou, M. and Nodehi, N. (2016). Relationship between some environmental factors with distribution of medicinal plants in Ghorkhud protected region. Journal of Rangeland Science. 6(1): 63-72.

Anonoymous. Vision-(2030). Directorate of Medicinal and Aromatic crops, Anand, Gujarat, India, 2013. http://www.dmapr.org.in/.

Argyropoulou, K., Salahas, G. Hela, D. and Papasavvas, A. (2015). Impact of nitrogen deficiency on biomass production, morphological and biochemical characteristics of sweet basil (Octimum basilicum L.) plants, cultivated aeroponically. Agri. \& Food. 3:3242.

Arnold., P.A. Kruuk, L.E. and Nicotra, A.B. (2019). How to analyse plant phenotypic plasticity in response to a changing climate. New Phytol. 222(3):1235- 41. https://doi.org/10.1111/nph.15656.

Balky, S. A. (1998). Effect of fertilization treatments on yield of Chryslar Imperial rose plants. Agric. Res. Rev. 52:95-99.

Bauer, A. and Brönstrup, M. (2014). Industrial natural product chemistry for drug discovery and development. Natural Prod. Rep. 31 (1), 35-60. 10.1039/C3NP70058E
Begum, F., Bajracharya, R.M. Sharma, S. and Sitaula, B.K. (2010). Influence of slope aspect on soil physico-chemical and biological properties in the mid hills of central Nepal. Int. J. Sustain. Dev. World. 17: 438-443.

Berini., J.L. Brockman, S.A. Hegeman, A.D. Reich, P.B. Muthukrishnan, R. Montgomery, R.A. and Forester, J.D. (2018). Combinations of abiotic factors diferentially alter production of plant secondary metabolites in five woody plant species in the boreal-temperate transition zone. Front Plant Sci. 9:1257. https://doi.org/10.3389/fpls.2018.01257.

Black, C.A. (1968). Soil Plant Relations. J. Wiley and Sons. New York.

Bortharkur, D.N. (1992). Agriculture of Northern Eastern Region with Special Reference to Agriculture. BeeCee Prakashan, Guwahati.

Boroomand, N., Marezi, A. Sadat, H.G.M. (2011). Effect of organic and phosphorus on mineral and yield of Ocimum basilicum. 7th Iranian Congress of Horticultural Science, Isfahan, Iran. 363-368.

Bu, R. Lu, J. Ren, T. Liu, B. Li, X. Cong, R. (2015). Particulate Organic Matter Affects Soil Nitrogen Mineralization under Two Crop Rotation Systems. PLoS One. 10(12):e0143835.

https://doi.org/10.1371/journal. pone.0143835 PMID: 26647157.

Buckman, H.O. and Brady, N.C.(1967). The nature and properties of soils. Eurasia Publishing House (Pvt) Ltd. New Delhi.

Chen, L., Li, P. and Yang, Y. (2016).Dynamic patterns of nitrogen: Phosphorus ratios in forest soils of China under changing environment. J. Geophys. Res. Biogeosci. 121. 2410-2421.

Chetri, S.P.K. Sharma, K. Agrawal, V. (2013). Genetic diversity analysis and screening of high psoralen yielding chemotype of Psoralea corylifolia from different regions of India employing HPLC and RAPD marker. Int $J$ Plant Res. 26:88-95.https ://doi.org/10.5958/j.2229-4473.26.2s.126.

Dominati, E. Patterson, M. and Mackay, A. (2010). A framework for classifying and quantifying the natural capital and ecosystem services of soils. Ecol. Econ. 69: 1858-1868.

Fahimipoor, A., Zare Chahouki, M. A. and Tavili, A., 2010. Study of relationship some species 
with environmental factors (Case Study: Part of the Taleghan rangelands). J. Rangeland. 13 (1): 32-23.

Faizul, B. Karlw, D.M. Murray, L. (1995). Livestock grazing impacts on infiltration rates in a temperate range of Pakistan. J. Range Manage.46: 367-372.

Gao, H., Bai, J. He, X. Zhao, Q. Lu, Q. and Wang J. (2014). High temperature and salinity enhance soil nitrogen mineralization in a tidal freshwater marsh. PLoS One. 9(4):e95011. https://doi.org/10.1371/journal.pone.0095011 PMID: 24733366.

García-Ruiz, R., Ochoa, V., Vinegla, B., Hinojosa, M.B., Pena-Santiago, R., Liebanas, G., Linares, J.C., Carreira, J.A. (2009). Soil enzymes, nematode community and selected physico-chemical properties as soil quality indicators in organic and conventional olive oil farming: Influence of seasonality and site features. Appl. Soil Ecol. 41, 305-314.

Hardy, D.H. Tucker, M.R. and Stokes, C.E. (2013).Understanding the soil test report. NC Department of Agriculture \& Consumer Services, Agronomic Division.

Hook, P.B. and Burke, I.C. (2000). Biogeochemistry in a shortgrass landscape: Control by topography, soil texture, and microclimate. Ecol. 81:2686-2703.

Jackson, M.L. (1967). Soil chemical analysis. Asia Publication House, Bombay. p. 498

Jackman, R.H. (1964). Accumulation of organic matter in some New Zealand soils under permanent pasture I. Patterns of change of organic carbon, nitrogen, sulphure and phosphorus. NZ. J. Agri. Res. 7: 445-471.

Jafari, M., Rostampoor, M. Tavili, A. Zare Chahouki, M. A. and Farzadmehr, G. (2008). Direct gradient analysis of plant species and environmental factors in the ecological groups Zirkuhe Ghaen rangelands. J. Range. 2 (4): 343-339.

Janisva, M. (2005). Vegetation-environment relationship in dry calcareous grassland. Jour. Ekologia-Bratislava. 24 (1): 25-44.

Jenny, H. (1930). A study on the influence of climate upon nitrogen and organic matter content of soil Missouri. Agri. Expt. Stat. Res. Bull., p.152.

Kala, C.P. (2000). Status and conservation of rare and endangered medicinal plants in the
Indian trans-Himalaya. Biol. Conserv. 93:371379.

Kala, C.P. (2005). Community composition, species diversity, and secondary succession in grazed and ungrazed alpine meadows of the West Himalaya, India. Int. J. Fiel. Std. 2(1).

Keoghh, J.L. and Maples, R. (1972). Variation in soil test results as affected by seasonal sampling. Bulletin, Arkansas Agricultural Experiment Station. No. 777, p. 26. Arkansas University, Fayetteville, USA, 123: 715-783.

Khan, F., Hayat, Z. Ahmad, W. Ramzan, M. Shah, Z. Sharif, M. Mian, I.A. Hanif, M. (2013). Effect of slope position on physico-chemical properties of eroded soil. Soil Environ. 32, 22-28.

Kharkwal, G. and Rawat Y.S. (2010). Structure and composition of vegetation in subtropical forests of Kumaun Himalaya. Afr. J. Plant. Sci. 4(4): 116-121.

Kharkwal, G., Rawat, Y.S. and Pangtey, Y.S. (2009). An ordination of the forest communities in Nainital catchment of Kumaun Himalaya. J. Env. Biol., 30 (5): 853857.

Khormali, F., Ayoubi, S. Foomani, F.K. Fatemi, A. and Hemmati, K. (2007). Tea yield and soil properties as affected by slope position and aspect in Lahijan area, Iran. Int. J. Plant Prod. 1: 245-259.

Kooch, Y., Bahmanyar, H. J. M. A. and Pormajidian, M. R. (2007). Ecological distribution of indicator species and effective edaphical factors on the Northern Iran lowland forests. Jour. Applied Science. 7: 1475-1483.

Kroymann, J. (2011). Natural diversity and adaptation in plant secondary metabolism. Current Opin. Plant Biol. 14(3):246-51. https://doi. org/10.1016/j.pbi.2011.03.021.

Kumar, S., Sharma, J.C. and Sharma, I.P. (2002). Water retention characteristics and erodibility indices of some soils under different land uses in northwestern Himalayas. Ind. J. Soil Cons. 30(1): 29-35.

Li Q. L. and Xiao, H. L. (2012). The interactions of soil properties and biochemical factors with plant allelopathy. Ecol. and Environ. Sci. 21: 2031-2036.

Liu, H. Y., Xu, L. H. Chen, C. D. Cui, H. T. and $\mathrm{Xu}, \mathrm{X}$. Y. (2002). Vegetation patterns and 
nature reserve construction in an extremely arid desert in Anxi, NW China's Gansu province. J. Environ Sci. 14: 380-387.

Liu, Y., Zhang, Z. S. He, Y. L. Zhang, B. G. and Li, X. E. (2007). Quality of crude traditional Chinese drugs and ecological environment. Modernization of Traditional Chinese Medicine and Materia Materia-World Science and Tech. 9: 65-69.

Liu, R., Pan, Y. Bao, H. Liang, S. Jiang, Y. Tu, H. Nong, J. and Huang, W. (2020). Variations in Soil Physico-Chemical Properties along Slope Position Gradient in Secondary Vegetation of the Hilly Region, Guilin, Southwest China

Loveland, P. and Webb, J. (2003). Is there a critical level of organic matter in the agricultural soils of temperate regions: A review. Soil Tillage Res. 70: 1-18.

Lozano-García, B., Parras-Alcántara, L. Brevik, E.C. (2016). Impact of topographic aspect and vegetation (native and reforested areas) on soil organic carbon and nitrogen budgets in Mediterranean natural areas. Sci. Total Environ. 544: 963-970.

Marschner, H. 1995. Mineral nutrition of higher plants. $2^{\text {nd }}$ ed. Academic Press, London, UK.

Mengel, K. and Kirkby, E. A. (1987). Principles of plant nutrition. Bern: International Potash Institute.

Michael P (1984). Ecological methods for field and laboratory investigations. Tata Mcgraw Hill Pub. Comp. Ltd

Mobley, M.L. (2009). Monitoring Earth's critical zone. Sci. 326: 1067-1068.

Morison, J.I.L. Lawlor, D.W. (1999). Interactions between increasing $\mathrm{CO}_{2}$ concentration and temperature on plant growth. Plant Cell Environ. 22:659-82. https://doi.org/10.1046/j.1365-3040. 1999.00443.x.

Nagappa, D. and Thirumala, S. (2014). Effect of Bio-Fertilizers on Growth and Biomass of Coleus Vettiveroides, Intern. J..Adv. Agri. Sci. and Tech. 3(1):53-57

Piper, C.S. (1966). Soil and Plant Analysis. Hans Publisher, Bombay.

Raina, J.N (1988). Physico-chemical properties and available macronutrient status of citrus growing soils of Poanta valley in Himachal Pradesh. Him. J. Agri. Res. 2: 71-78.
Ramakrishna, A. Ravishankar, G.A. (2011). Influences of abiotic stress signals on secondary metabolites in plants. Plant Signal Behav. 6(11):1720-31. https ://doi.org/10.4161/psb.6.11.17613.

Robinson, D.A. Panagos, P. Borrelli, P. (2017). Soil natural capital in Europe; a framework for state and change assessment. Sci. Rep. 7: 6706.

Salardini, A. (1979). Relationship between soil and plant, University of Tehran Press.

Sebastia, M.T. (2004). Role of topography and soils in grassland structuring at the landscape and community scales, Basic Appl. Ecol. 5: 331-346.

Shameem, S. A., Kangroo, I. N. and Bhat, G. A. (2011).Comparative assessment of edaphic features and herbaceous diversity in lower Dachigam national park,Kashmir, Himalaya. J. Ecol. and the Nat. Environ. 3(6).196-204.

Shameem, S. A., Mir, I. A. Irfana, N. K. and Shams-ud-T. (2017). Impact of Grazing Intensity on Phytodiversity of Herbaceous Vegetation at High Altitude Pasturelands of Gulmarg Range, Kashmir Valley (J \& K). Int. J. Pure App. Biosci. 5 (2): 1025-1041.

Shameem., S. A. Mushtaq, H. Wani, A. A. Ahmad, N. (2017). Phytodiversity of Herbaceous Vegetation in Disturbed and Undisturbed Forest Ecosystems of Pahalgam Valley, Kashmir Himalaya, India. Brit. J of Environ \& Clim. Chang. 7(3): 148-167, 2017; Article no.BJECC.2017.012. ISSN: 22314784.

Sheikhhosseini, A. R. and Noorbakhsh, F. (2007). Effect of soil type and plant residues on mineralization intensity of pure nitrogen, $J$. Res and Dev. 127: 75-133.

Shourkaie, S. G. Chaichi, M.R. Saravi, M.M. Hosseini, H.M.S. Lotfollahi, M. (2007). Evaluation of grazing intensity effects on organic matter content and mineral nutrients recycling in rangeland soils (Case study: Mirza Bailue Rangelands, Golestoan Province, Iran).

Simek, M. and Cooper, J.E. (2002). The influence of soil $\mathrm{pH}$ on denitrification: Progress towards the understanding of this interaction over the last 50 years. Eur. J. Soil Sci. 53, 345-354.

Sun, F.X., Lu, Y.H. Fu, B.J. Ma, Z.M. Yao, X.L. (2014). Spatial explicit soil moisture analysis: 
Pattern and its stability at small catchment scale in the loess hilly region of China. Hydrol. Process. 28: 4091-4109

Taghipoor, A., Mesdaghi, M. Heshmati, G.H. Rastegar, S.H. (2008). Effect of environment factors on distribution species in BehshahrHezarjarib rangeland. J. Agron and Nat. Res. Sci. 4(66): 195-207.

Tsui, C.C., Chen, Z.S. and Hsieh, C.F. (2004). Relationships between soil properties and slope position in a lowland rain forest of southern Taiwan. Geoderma.123: 131-142.

Umali, B.P., Oliver, D.P. Forrester, S. Chittleborough, D.J. Hutson, J.L. Kookana, R.S. Ostendorf, B. (2012). The effect of terrain and management on the spatial variability of soil properties in an apple orchard. Catena. 93: 38-48.

Verma S, Nizam S, Verma PK. Biotic and abiotic stress signalling in plants. Stress Signaling in Plants: Genomics and Proteomics Perspective. 2013; 1: 25-49

Virtanen, R., Oksanen, J. and Razzhivin, V. Y. (2006). Broad-scale vegetation- environment relationships in Eurasian high-latitude areas. J. Veg. Sci. 17(4): 519-528.

Virtanen, R., Oksanen, J. and Razzhivin, V. Y. (2006). Broad-scale vegetation- environment relationships in Eurasian high-latitude areas. Jour. Vegetation Science. 17(4): 519-528.

Walkey, A. E. and Black, J.A. (1934). An examination of the Degtiga vett method for determining soil organic matter and proposed modification of the chromic acid titration method. Soil Sci., 37: 29.

Walz, J., Knoblauch, C. Bo"hme, L. and Pfeiffer, E.M. (2017). Regulation of soil organic matter decomposition in permafrost-affected Siberian tundra soils-Impact of oxygen availability, freezing and thawing, temperature, and labile organic matter. Soil Biol. and Bioch. 110:34-
43.

Weekley, C.W. and Race, T. (2001). The breeding system of Ziziphus celata Judd and D.W. Hall (Rhamnaceae), a rare endemic plant of the lake water ridge, Florida, USA: Implications for recovery. Biol. Conserv.113: 389-398.

Yang, L., Wen K.S. Ruan, X. Zhao, Y.X. Wei, F. Wang, Q. (2018). Response of plant secondary metabolites to environmental factors. Molecules. 23(4):E762. https://doi.org/10.3390/molecules23040762.

Yimer, F., Ledin, S. and Abdelkadir, A. (2006). Soil property variations in relation to topographic aspect and vegetation community in the south-eastern highlands of Ethiopia. For. Ecol. Manag. 232: 90-99.

Yu, Y.C., Yang, J.Y. Zeng, S.C. Wu, D.M. Jacobs, D.F. and Sloan, J.L. (2017). Soil pH, organic matter, and nutrient content change with the continuous cropping of Cunninghamia lanceolata, plantations in South China. J. Soil Sediments. 17: 2230-2238.

Zhang, X.Y., Liu, M.Z. Zhao, X. Li, Y.Q. Zhao, W. Li, A. Chen, S. Chen, S.P. Han, X.G. and Huang, J.H. (2018). Topography and grazing effects on storage of soil organic carbon and nitrogen in the northern China grasslands. Ecol. Indic. 93: 45-53

Zolfaghari, F., Pahlevanravi, A. Fakhireh, A. and Jabari, M. (2010). Relationship between environmental factors on the distribution of vegetation in Aghtagheh watershed. Jour. Range and Iran Desert. 17(3): 431-444.

Zykin, P.A. Andreeva, E.A. Lykholay, A.N. Tsvetkova, N.V. Voylokov, A.V. (2018). Anthocyanin composition and content in rye plants with different grain color. Molecules. 23:948. https ://doi.org/10.3390/molecules230409 48.

\section{How to cite this article:}

Aijaz Ahmad Sheikh, S.A. Shameem and Naseer Ahmad. 2020. Impact of Biotic Stress on Edaphic Features Under two Important Medicinal Plants (Podophyllum hexandrum and Rumex acetosa L.) of Kashmir Valley, J \& K, India. Int.J.Curr.Microbiol.App.Sci. 9(06): 859-873. doi: https://doi.org/10.20546/ijcmas.2020.906.109 